\section{7. 中小企業における各種塵肺検診成績について}

大島 竜男, 岡田 静雄, 田中 開

岡崎 正義, 浅海 通太

（結核尒防会大阪府支部）

瀬良 好澄，横山邦意

（国立大阪雴生团）

我々は大阪市及び周辺の中小企業を対象として，昭和 35年8月1日より 12 月 10 日までの間に, 105 軎業場, 2,223 人ついて塵肺法に基く各種塺肺检診を実施したの で，その成績を報告する。

検診方法㤬，全員について詳細なる職歴調查，内科檢 診，X線直接撮影を実施し，X線上，䴣肺有听見者には 肺機能検查を，また結核有所見者には結核精密検診を実 施した。

我々の実施した事業場は比較的小企菜（50人以下）が 多く，粉嚴環境の良好な大企業にくらべると，すべての 点で環境面は不良であり，これら小企業に拈ける㕍棜発 生頻度は，大企業のそれと比較検討したとき，興味ある 成績を得た。

総数 2,223 例中， 1 型97例 $(4.36 \%) ， 2$ 型37例 (1.16

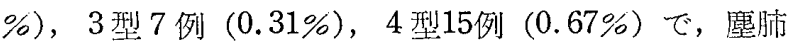
有所見者合計は 156 例 $(7.0 \%)$ であった。

また，この注か塺肺の疑と考光られるもの132例(5.98 \%）が認められた。

これらの成績から，大企業に扣いても，軽度の麈肺は かなり多く見られるが，3型・4型の如く進展したもの は少ないにもかかわらず，我々の検診した小企業体では 4 型が $0.67 \%$ に見られたことは，都市に拉ける壓肺所 見としては注目に価することであろら。

また結核有所見者は 112 例 (4.88\%) であったが，こ の数字はよく管理された企業体とあまり大きな差は見ら れなかった。これは塵脑と異なり，結核管理は現在では 小企業でも，かなり実施されているためと見られ，興味 深い。

このほか学会においては職種別, 年令別, 塵肺発生䫍 度及び肺機能検査の結果について詳細に報告する。

\section{8． 珪脑患者の骨蹃機能について（第 1 報）}

柴田 完，西村 文夫

(岡山労災病院内科)

珪肺症の末梢血液像は比較的古くから研究，かつ報告 されており，また骨髄像も研究されているが，骨髄の体 外組織培養は行なわれていない。私達は血液像を追求し

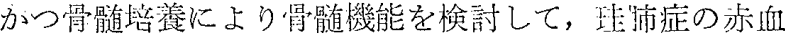
球系の変化を解明せんと試みた。そこでまず Roller tube 法により，骨䯣穿刺液の液体培養を行なったので 報告する。

玨肺患者の胸骨穿刺により，胸骨骨髄 $0.4 \mathrm{cc}$ を採取 し，ただもに予じめ用急して和いた Gey 液中 $7 \mathrm{cc}$ に注 入， 1500 迴転 7 分間遠沈し，沈渣をこれも子じめ用意し ておいたTyrode 「液及び汇液を $7 \mathrm{cc}$ 等量に混和した 三角フラスコにとり，㪕く振䔽して充分に混和した骨䯣 浮遊液を作り，ワッセルマン試鍈管に患者血清 $0.5 \mathrm{cc}$ と 上記浮遊液を $1.5 \mathrm{cc}$ の割合に混合する。かくの如くして 作られた被検物を roller tubeにより，1時間16回転

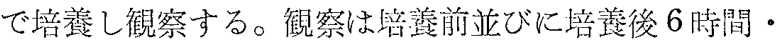
12㭙間・24封間・36特間及び48封間ごとに行ない，その 都度，赤血球数を算定し，各㭙間ごとの赤血球增加率を 求める。

かかる培羪実験結果では，同年命の健康人の赤血球増 加率に比して，琵䏳態者のそ机はより简い值を祭し，か つ下降はよりゆるやかであることを認めた。

な括骨骫有のジデロブラスト，末梢血の赤血球数・血色 素量・色素指数・赤血球值経・赤血球の滲透圧に対与る 抵抗・血清銅・血清鉄等と比校愉馀した。

189. 塵肺症の喀痰に関する検討 $(\Pi)$ 般細菌培養成綪について

阿部 彰, 山本二三子，山上次郎 （珪肺労㷋病院）

塺胴症における喀痰量の增加, 喀痰中兏分量の增加, さらK気管支像に括ける屈曲, 狭窄, 应張等の形態学的 な変化を示す点から，慢性気管支災の合併の有眫，並び に細菌感染の有血を検討する目的にて，塺拈並びに塺斾

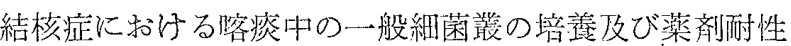
を検討した。喀痰の濃栓部を生理的食塩水で洗滌後，血 液培地に培養し，とくにブドウ球菌，真菌は分離培差を 行ない，さらに感応錠試験を行なった。

（1）塵肺症25例（主として金属山坑内夫，21例は塊状 陰影の合僧例）の培兹成績では，白色，黄色ブドウ球 菌， $\alpha, \beta, \gamma$ 連鎖球菌，グラム陽性欢球菌，ナイセリア

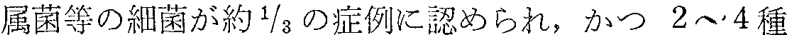
の細菌が同時に認られる症例が最も多い。一部には真菌， 枯草菌曲浔められた。

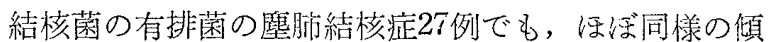
向があったが，ブドウ球菌，連政球菌の出現している症 例が前者に比してやや多く, 非排菌の歴拉結㤥10例では 